Original Research Paper

\title{
Assessing the Impact of Community Life Improvement Program (CLIP) on the Livelihood Assets of Women in the Sheabutter Processing Business in Karaga District of Northern Ghana
}

\author{
${ }^{1}$ Alhassan Bawa, ${ }^{2}$ Paschal B. Atengdem and ${ }^{3}$ Safia Choo Abukari \\ ${ }^{I}$ Department of Agronomy, Faculty of Agriculture, University for Development Studies, Tamale, Ghana \\ ${ }^{2}$ Department of Agricultural Extension, University of Ghana, Legon, Accra, Ghana \\ ${ }^{3}$ Nyankpala Islamic Basic School, Nyankpala, Ghana
}

Article history

Received: 07-10-2016

Revised: 13-06-2017

Accepted: 19-06-2017

Corresponding Author:

Alhassan Bawa

Department of Agronomy,

Faculty of Agriculture,

University for Development

Studies, Tamale, Ghana

Email: abawai1@yahoo.com

\begin{abstract}
The poverty situation in Northern Ghana is a major challenge to sustainable development. As a result of socio-cultural factors, women are vulnerable and their poverty situation is even more overwhelming. Development agencies, Governmental and Non-Governmental Organizations have adopted and implemented different strategies aimed at reducing poverty in these areas. Micro-credit delivery to the poor especially women is one of these strategies that seems to be making impact towards improving the livelihoods of the rural poor women. The Community Life Improvement Program (CLIP), a Non-Governmental Organization has instituted a micro-credit scheme to help the poor rural women in Karaga district of Northern region to expand their sheabutter processing microbusiness. The objective of the study was to assess the impact of the CLIP Project on the livelihood assets of sheabutter processing women in Karaga district of Northern region. Purposive and snowball sampling techniques were used to select 110 respondents $(80$ beneficiary and 30 non-beneficiary women) who were interviewed for the study. Interview guide and focus group discussions were tools used to obtain information from the sheabutter processing women. The results of the study revealed that the livelihood assets of the beneficiary women have been improved. The study further revealed that the livelihood assets of the beneficiary women were far better off as compared to that of the non-beneficiary women of the CLIP Project. The study recommended that, the CLIP Project should extend its financial services to many more non-beneficiary sheabutter processing women in the target communities.
\end{abstract}

Keywords: Likelihood Assets, Sheabutter Processing, CLIP Project, Women Groups, Ghana

\section{Introduction}

In Ghana, women play a major role in household sustenance and contribute immensely to community development. Women form the dominant entrepreneurs in the informal micro-enterprise activities. Eighty (80) percent of female labour force is in small-scale industries in Ghana (NCWD, 1997). However, majority of these women do not have adequate access to capital and training. Sheabutter processing, groundnut oil processing, local soap production and petty trading are some of the major activities that these women are engaged in and which can improve the livelihoods of rural women (Caldas et al., 2007). It is against this background that the Community Life Improvement Program (CLIP) is embarking on micro-credit scheme in the Karaga, Gushegu and Yendi districts of the Northern region of Ghana to provide financial and social intermediation services to women to enable them improve upon their micro-businesses for improved livelihoods. 
Livelihood assets are the basic livelihood building blocks. Poverty analyses have shown that people's ability to escape from poverty is critically dependent on their access to assets (Booth et al., 1998). The livelihood framework identifies five core asset categories or types of capital upon which livelihoods are built. These include human, social, natural, physical and financial capital. Livelihood strategies is used to denote the range and combination of activities and choices that people make or undertake in order to achieve their livelihood goals (including productive activities, investment strategies, reproductive choices, etc.). Poor people usually pursue a diverse portfolio of activities, including on-farm activities, off-farm activities and migration, using their livelihood assets.

Impact assessment is a management mechanism aimed at measuring the effects of projects on the intended beneficiaries (Afrane, 2000). The rationale is to ascertain whether the resources (inputs) invested in the livelihood activity produced the expected level of output and benefit and contributed to fulfilling the mission of the project. The CLIP Project plays an important role in improving the lives of rural poor and vulnerable people in Yendi, Gushegu and Karaga districts of the Northern region of Ghana. The study is therefore, intended to evaluate the impact of CLIP Project on the livelihood assets of women in the micro-scale shea industry in Karaga district; and to determine if there was any difference between livelihood assets of beneficiary and non- beneficiary women of the CLIP Project.

\section{Methodology}

\section{Study Area}

The study was carried out in Karaga district of Northern region of Ghana. The Karaga district is located in the northeastern portion of the Northern region between latitudes $9^{\circ}$ $30^{\circ}$ and $10^{\circ} 30^{\circ}$ North and longitudes $0^{\circ}$ and $45^{\circ}$ West (PHC, 2010). The approximate land area of Karaga district is $5,796 \mathrm{~km}^{2}$ with a population of 77,706 ; consisting of 37,336 males and 40,370 females (PHC, 2010). Femaleheaded households are made up of $11.8 \%$ in the district, with an average household size of 10 members.

The vegetation is a typical Guinea-Savannah type, characterized by tall grasses interspersed with drought resistance trees such as the Shea and Dawadawa. Almost every household in the district rears some animals of a kind (PHC, 2010). There is no established industry in the district. However, there are over one hundred groups engaged in various income generating activities, which include: Sheabutter extraction by women groups and smock weaving by men. Low agricultural productivity and lack of ready markets for produce from income generating activities are some of the root causes of poverty in the district. The district is, however, endowed with a strong renewable resources base that offers potentials for enhanced agricultural productivity.

\section{Research Design}

The two groups in this study were the beneficiary and non-beneficiary women's groups. The main difference between the two groups is that one group receives support from the CLIP Project whilst the other group does not. Method of data collection employed in this study was the use of interview guide, questionnaire and check list for focus group discussion. The instruments comprised of a structure of open-and closed-ended questions. Interview guide and questionnaires are a good way of collecting information quickly and relatively cheaply as long as respondents are sufficiently disciplined to abandon questions that are superfluous to the main task (Bell, 1993). The interview guide and check list were employed for face-to-face interviewing of the beneficiary and non-beneficiary women of CLIP. The research instruments were pre-tested at Gaa in the Gushegu district of the Northern region where there were similar micro-scale sheabutter processors. This process exposed all inconsistencies and wrong expressions in the prepared questionnaires, which resulted in making of the necessary corrections before they were taken to the field of study.

For this study, the population comprised of:

- All the CLIP Project beneficiary women groups in the Karaga district

- All the CLIP Project non-beneficiary women groups in the Karaga district

\section{Sampling Technique and Sample Size}

The purposive sampling technique was used to select the CLIP Project, out of several NGOs that operate in the Karaga district, for the study. The Karaga district was selected through simple random sampling from the three operational districts of Yendi, Gushegu and Karaga. All the CLIP Project beneficiary communities within the Karaga district were used for the study. These include: Tong, Nyong-Nayili, Nyong-Guma, Bagurugu, YamoKaraga and Yamo-Karaga yapala. Each beneficiary community consisted of one women's group. All the eighty (80) beneficiary women were used for the study. The snowball sampling technique was used to select thirty (30) non-beneficiary women sheabutter processors in the six (6) beneficiary communities. A total of 110 respondents were used for the study.

\section{Statistical Analysis}

Both qualitative and quantitative tools of analysis were employed in data analysis. Prior to the analysis, the data were coded. Analysis was done using the 
Statistical Package for Social Sciences (SPSS). Cross tabulations of variables were done and the chi-square tests used to establish relationships. The TwoIndependent-Samples Tests analyses were also run to compare the beneficiary and non-beneficiary women with respect to some specific variables. Summaries of findings were presented in graphs and tables.

\section{Results}

\section{Social Characteristics of the Study Population}

\section{Age of Respondents}

Age is an important social factor in determining the working ability of any person (Atengdem, 1997). For the purpose of analysis, ages of respondents were classified into three categories as: Less than 40 years, 40 to 60 years and more than 60 years. The percentage age distribution of respondents into these age categories is presented in Fig 1. For the beneficiaries of the CLIP Project, $56.3 \%$ of them were between the ages of 40 to 60 years whilst $10 \%$ of them were above 60 years of age. For the non-beneficiary women of the CLIP Project, $63.3 \%$ of them were below 40 years whilst $10 \%$ of them were above 60 years.

\section{Marital Status of Respondents}

Marriage is an important institution in most Ghanaian communities. As illustrated in Fig. 2 below, most of the CLIP Project beneficiaries (93.8\%) and the nonbeneficiaries $(90 \%)$ were married.

\section{Level of Respondents' Education}

Education has been identified as one of the major components of empowerment. According to Sai (1994), education increases women's self-esteem and sense of control over personal destiny. The study revealed that $85 \%$ of the CLIP Project beneficiary women and $80 \%$ of the non-beneficiary women had no formal education (Fig. 3).

\section{Enhanced Social Capital}

DFID (1999) reported that social capital is developed through networks and connectedness, membership of more formalised groups, relationship of trust, reciprocity and exchange that facilitates co-operation, reduce transaction cost and may provide the basis for informal safety nets among the poor. Based on the findings of DFID, the researcher came out with seven-point conditions for enhanced social capital. Therefore, for a respondent's social capital to be enhanced, she should have satisfied all the seven conditions. The conditions are as follows:

- Working in a group

- Feeling part of the group

- Involvement in sharing of information/ideas with group members

- Sharing of information/ideas should occur most frequently (either weekly or bi-weekly)

- Participation in all or most of group activities

- Enhanced ability to make friends

- Enhanced ability to work with other people in the group

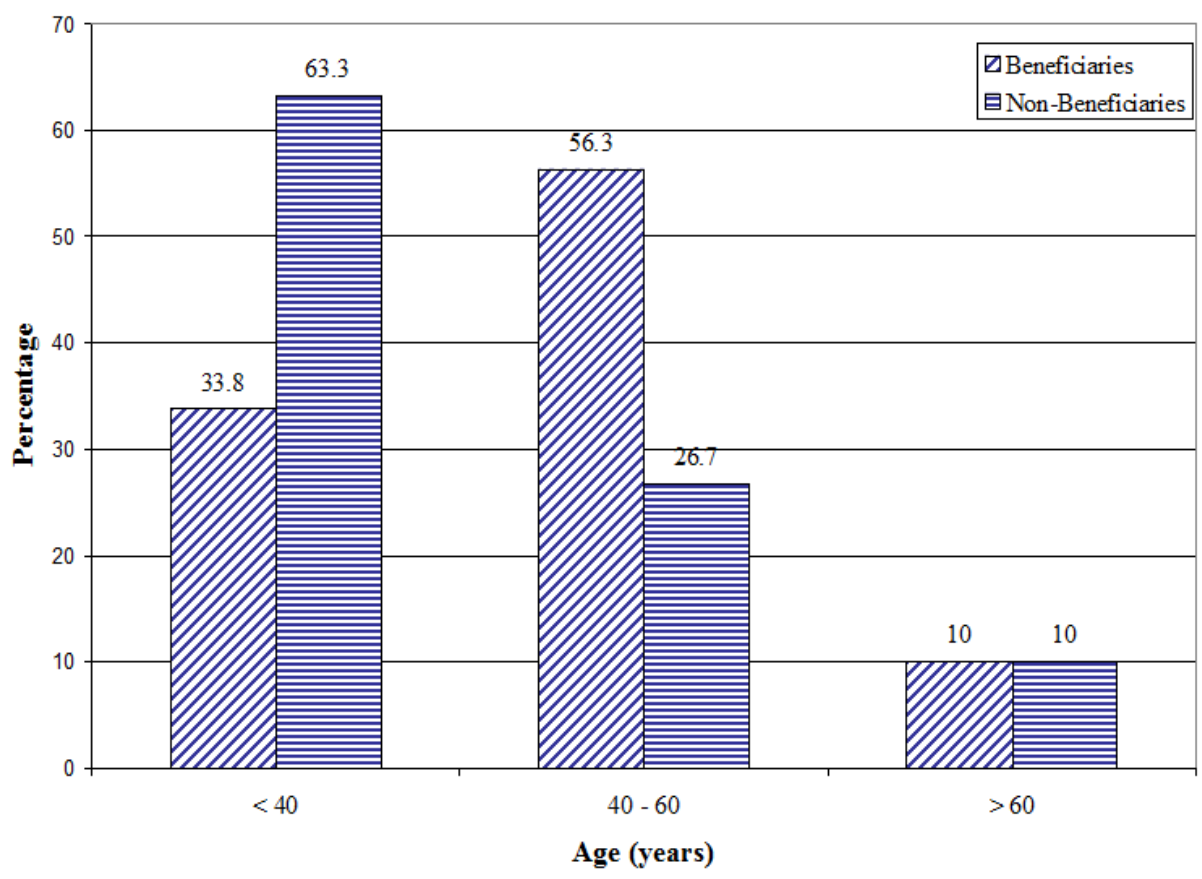

Fig. 1. Percentage distribution of respondents by age; Source: Field survey 2012 


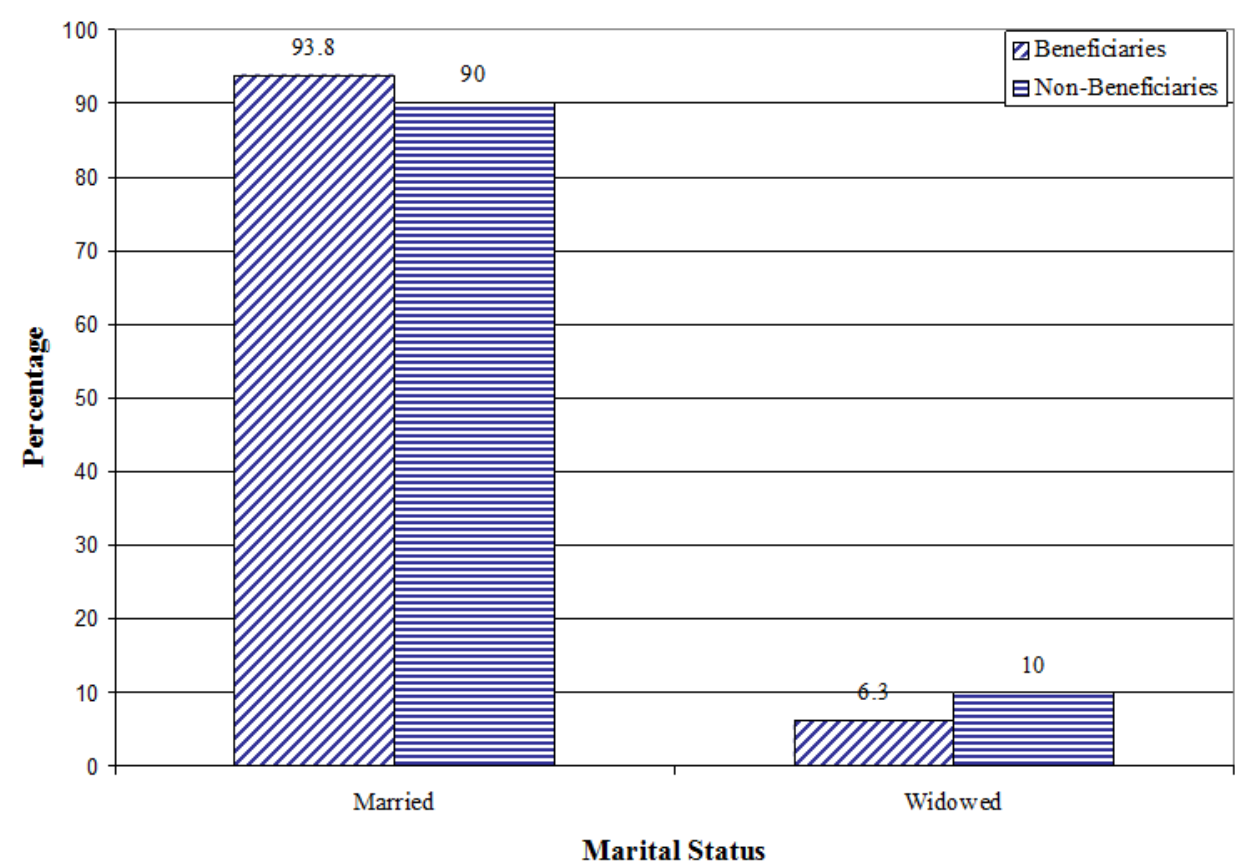

Fig. 2. Percentage distribution of respondents by marital status Source: Field survey 2012

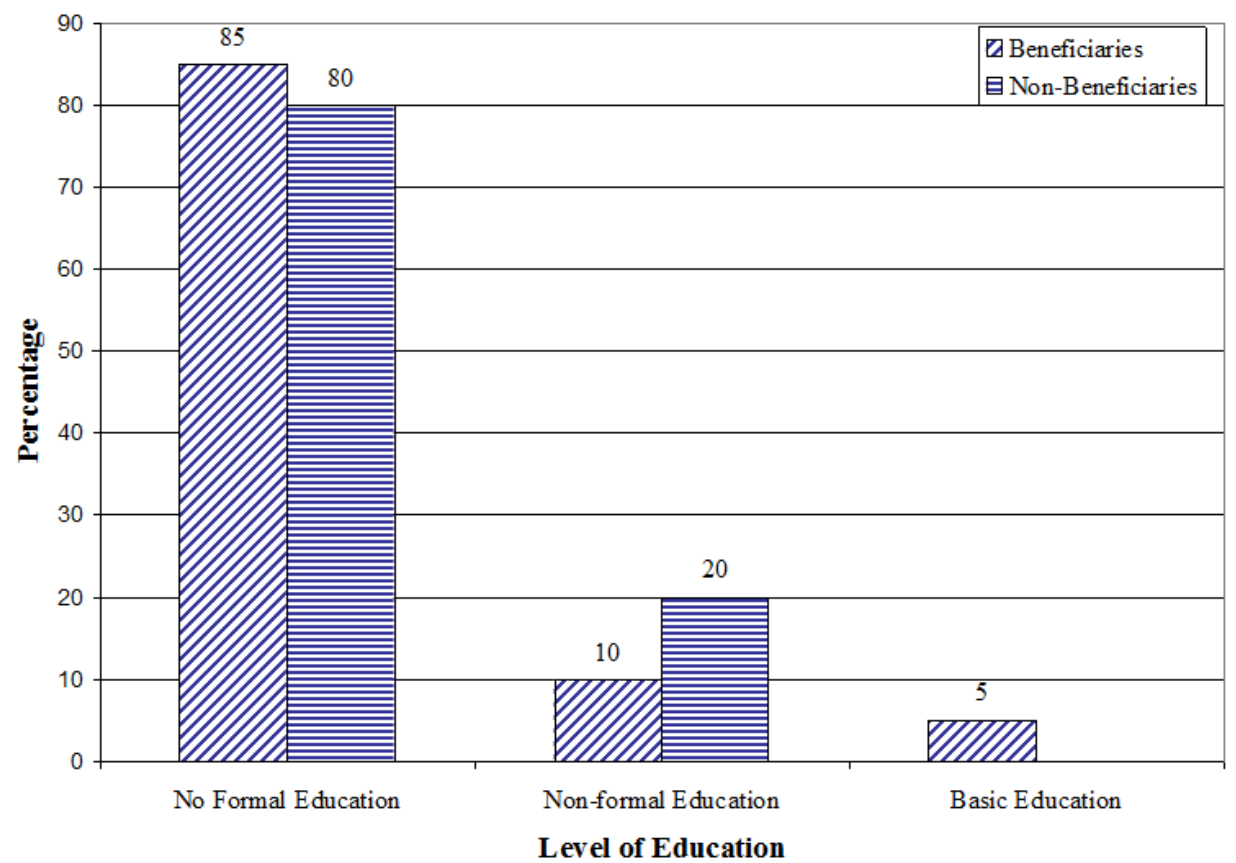

Fig. 3. Percentage distribution of respondents by level of education Source: Field Survey 2012

Table 1. Enhanced social capital

\begin{tabular}{llrr}
\hline Respondents & Number of conditions which have been satisfied & Frequency of responses & Percentage \\
\hline Beneficiaries & 4 & 1 & 1.25 \\
& 5 & 2 & 2.50 \\
& 6 & 8 & 10.00 \\
& 7 & 69 & 86.25 \\
& Total & 80 & 100.00 \\
\hline
\end{tabular}

Source: Field Survey 2012; Note: seven conditions are the total conditions to be satisfied 
Majority $(86.25 \%)$ of the beneficiary women of the CLIP Project have satisfied all the seven conditions for enhanced social capital (Table 1).

\section{Enhanced Human Capital}

Human capital represents the skills, knowledge, formal and informal education, local ecological knowledge, ability to labour and good health that together enable people to pursue different livelihood strategies and achieve their livelihood objectives (Ellis, 2000). Based on the findings of Ellis, the researcher came out with three-point conditions for enhanced human capital. Therefore, for a respondent's human capital to be enhanced, she should have satisfied all the three conditions. These include:

- Receive periodic training

- The training should be useful/very useful to the respondent

- Enhanced ability of respondent to access sheabutter processing skills

Majority of the beneficiaries (97.5\%) satisfied all the three conditions for enhanced human capital (Table 2).

\section{Enhanced Financial Capital}

According to DFID (1999), financial capital refers to the financial resources that people use to achieve their livelihood objectives. It includes credit, savings and remittances. The provision of these financial resources helps to develop the financial capital of people. Based on the findings of DFID, the researcher came out with three-point conditions for enhanced financial capital. Therefore, for a respondent's financial capital to be enhanced, she should have satisfied all the three conditions as follows:

- Her access to credit should be enhanced

- The credit granted her should be adequate to procure most of the sheabutter processing inputs

- The credit granted her should at least be timely

The study revealed that $33.75 \%$ of the beneficiary women satisfied all the three conditions for enhanced financial capital (Table 3).

\section{Enhanced Physical/Natural Capital}

DFID (1999) reported that affordable transport, secure shelter and building, adequate water supply and sanitation, clean affordable energy and access to information are necessary for sustainable development of physical capital. DFID (1999) added that there is a wide variation in the resources that make up natural capital, from intangible public goods such as the atmosphere and biodiversity to divisible assets used directly for production(trees, land, e.t.c). Based on the findings of DFID, the researcher came out with three-point conditions for enhanced physical/natural capital. Therefore, for a respondent's physical/natural capital to be enhanced, she should have satisfied all the three conditions. The conditions include:

- Exposure to new ideas in the sheabutter processing business

- Enhanced access to information

- Enhanced access to sheabutter processing inputs (e.g., processing equipment)

The results of the study showed that $90 \%$ of the beneficiary women have satisfied all the three conditions for enhanced physical/natural capital. For the nonbeneficiary women, majority of them $(76.70 \%)$ satisfied none of the three conditions for enhanced physical/natural capital (Table 4).

\section{Enhanced Livelihood Assets}

Poverty analyses have shown that people's ability to escape from poverty is critically dependent on their access to livelihood assets (Booth et al., 1998). The livelihood framework identifies five core assets categories or types upon which livelihoods are built. These include human, social, natural, physical and financial assets. People's livelihood assets are developed if their access to the social, human, financial, physical and natural capital is improved. Based on the findings of Booth et al. (1998), the researcher came out with sixteen-point conditions for enhanced livelihood assets. Therefore, for a respondent's livelihood assets to be enhanced, she should have satisfied all the sixteen conditions as follows:

- Working in a group

- Feeling part of the group

- Involvement in sharing of information/ideas with group members

- Sharing of information/ideas should occur most frequently (either weekly or bi-weekly)

- Participation in all or most of group activities

- Enhanced ability to make friends

- Enhanced ability to work with other people in the group

- Receive periodic training

- The training should be useful/very useful to the respondent

- Enhanced ability of respondent to access sheabutter processing skills

- Enhanced access to credit

- The credit granted the respondents should be adequate to procure most of the sheabutter processing inputs 
- The credit granted them should at least be timely

- Exposure to new ideas in the sheabutter processing business

- Enhanced access to information

- Enhanced access to sheabutter processing inputs (e.g., processing equipment)

In general, $26.25 \%$ of the CLIP Project beneficiary women satisfied all the sixteen conditions for enhanced livelihood assets. For the non-beneficiary women of the CLIP Project, majority of them $(76.70 \%)$ satisfied none of the sixteen conditions for enhanced livelihood assets (Table 5).

\section{Social Characteristics of Beneficiary Women and Enhanced Livelihood Assets}

The study revealed the relationship between social characteristics of beneficiary women and enhanced livelihood assets. The social characteristics include: Age, marital status, level of education and period of membership of beneficiaries in groups.

\section{Age of Beneficiary Women and Enhanced Livelihood Assets}

The distribution of beneficiary women by age and enhanced livelihood assets is presented in Table 6. Out of the 27 beneficiary women who were less than 40 years of age, 26 satisfied thirteen or more of the sixteen conditions for enhanced livelihood assets. The chisquare test results showed that at 5\% confidence level, there was no significant difference between distribution of beneficiary women by level of enhanced livelihood assets with respect to their ages $\left(\chi^{2}=0.242\right.$, df $=1$, $0.10>\mathrm{p}>0.05)$. This implies that enhanced livelihood assets are independent of the age of beneficiary women. This is contrary to the findings of Atengdem (1997) who observed that age is an important social factor in determining the working ability of any person and that the ability of a person to work to improve on his/her livelihood depends on the age.

\section{Marital Status of Beneficiary Women and Enhanced Livelihood Assets}

The distribution of CLIP Project beneficiary women by marital status and enhanced livelihood assets is presented in Table 7 . Out of a total of 75 beneficiary women who were married, 73 of them satisfied thirteen or more of the sixteen conditions for enhanced livelihood assets. However, at 5\% confidence level, there was no statistical significant difference between distribution of beneficiary women by level of enhanced livelihood assets with respect to their marital status $\left(\chi^{2}=0.137, \mathrm{df}=1,0.10>\mathrm{p}>0.05\right)$. This implies that enhanced livelihood assets are independent of marital status of beneficiary women.

Table 2. Enhanced human capital

\begin{tabular}{llrr}
\hline Respondents & Number of conditions which have been satisfied & Frequency of responses & Percentage \\
\hline Beneficiaries & 2 & 2 & 2.5 \\
& 3 & 78 & 97.5 \\
& Total & 80 & 100.0 \\
\hline
\end{tabular}

Source: Field Survey 2012; Note: Three conditions are the total conditions to be satisfied

Table 3. Enhanced financial capital

\begin{tabular}{llcr}
\hline Respondents & Number of conditions which have been satisfied & Frequency of responses & Percentage \\
\hline Beneficiarie & 1 & 25 & 31.25 \\
& 2 & 28 & 35.00 \\
& 3 & 27 & 33.75 \\
& Total & 80 & 100.00 \\
\hline
\end{tabular}

Source: Field Survey 2012; Note: Three conditions are the total conditions to be satisfied

Table 4. Enhanced physical/natural capital

\begin{tabular}{|c|c|c|c|}
\hline Respondents & Number of conditions which have been satisfied & Frequency of responses & Percentage \\
\hline \multirow[t]{4}{*}{ Beneficiaries } & 1 & 1 & 1.25 \\
\hline & 2 & 7 & 8.75 \\
\hline & 3 & 72 & 90.00 \\
\hline & Total & 80 & 100.00 \\
\hline \multirow[t]{3}{*}{ Non-beneficiaries } & 0 & 23 & 76.70 \\
\hline & 1 & 7 & 23.30 \\
\hline & Total & 30 & 100.00 \\
\hline
\end{tabular}

Source: Field Survey 2012; Note: Three conditions are the total conditions to be satisfied 
Table 5. Enhanced livelihood assets

\begin{tabular}{|c|c|c|c|}
\hline Respondents & Number of conditions which have been satisfied & Frequency & Percentage \\
\hline \multirow[t]{7}{*}{ Beneficiaries } & 9 & 1 & 1.25 \\
\hline & 12 & 1 & 1.25 \\
\hline & 13 & 7 & 8.75 \\
\hline & 14 & 22 & 27.50 \\
\hline & 15 & 28 & 35.00 \\
\hline & 16 & 21 & 26.25 \\
\hline & Total & 80 & 100.00 \\
\hline \multirow[t]{3}{*}{ Non-Beneficiaries } & 0 & 23 & 76.70 \\
\hline & 1 & 7 & 23.30 \\
\hline & Total & 30 & 100.00 \\
\hline
\end{tabular}

Source: Field Survey 2012; Note: Sixteen conditions are the total conditions to be satisfied

Table 6. Distribution of beneficiary women by age and enhanced livelihood assets

\begin{tabular}{|c|c|c|c|}
\hline \multirow[b]{2}{*}{ Age } & \multicolumn{3}{|c|}{ Number of conditions which have been satisfied } \\
\hline & $\leq 12$ & $\geq 13$ & Total \\
\hline$<40$ & 1 & 26 & 27 \\
\hline$\geq 40$ & 1 & 52 & 53 \\
\hline Total & 2 & 78 & 80 \\
\hline
\end{tabular}

Source: Field Survey $2012 ; \chi^{2}=0.242, \mathrm{df}=1,0.10>\mathrm{p}>0.05$ not significant

Table 7. Distribution of beneficiary women by marital status and enhanced livelihood assets

\begin{tabular}{llrl}
\hline & Number of conditions which have been satisfied & \\
Marital status & - & $\geq 13$ & Total \\
\hline Married & $\leq 12$ & 73 & 75 \\
Widowed & 2 & 5 & 5 \\
Total & 0 & 78 & 80 \\
\hline
\end{tabular}

Source: Field Survey $2012 ; \chi 2=0.137, \mathrm{df}=1,0.10>\mathrm{p}>0.05$ not significant

Table 8. Distribution of beneficiary women by level of education and enhanced livelihood assets

\begin{tabular}{|c|c|c|c|}
\hline \multirow[b]{2}{*}{ Level of education } & \multicolumn{3}{|c|}{ Number of conditions which have been satisfied } \\
\hline & $\leq 12$ & $\leq 13$ & Total \\
\hline No formal education & 2 & 66 & 68 \\
\hline Non-formal/ basic education & 0 & 12 & 12 \\
\hline Total & 2 & 78 & 80 \\
\hline
\end{tabular}

Source: Field Survey $2012 \chi 2=0.362 \mathrm{df}=10.10>\mathrm{p}>0.05$ not significant

Table 9. Distribution of CLIP project beneficiary women by period of membership in groups and enhanced livelihood assets

\begin{tabular}{|c|c|c|c|}
\hline \multirow[b]{2}{*}{ Period of membership in groups } & \multicolumn{2}{|c|}{ Number of conditions which have been satisfied } & \multirow[b]{2}{*}{ Total } \\
\hline & $\leq 12$ & $\geq 13$ & \\
\hline$<4$ years & 0 & 54 & 54 \\
\hline$\geq 4$ years & 2 & 24 & 26 \\
\hline Total & 2 & 78 & 80 \\
\hline
\end{tabular}

Source: Field Survey $2012 ; \chi 2=4.260, \mathrm{df}=1,{ }^{* *} \mathrm{p}<0.05$ significant

\section{Level of Beneficiary Women's Education and Enhanced Livelihood Assets}

The distribution of CLIP Project beneficiary women by level of education and enhanced livelihood assets is presented in Table 8 . Out of the 68 beneficiary women who had no formal education, 66 satisfied thirteen or more of the sixteen conditions for enhanced livelihood assets. At 5\% confidence level, there was no significant difference between the different levels of enhanced livelihood assets with respect to educational level of beneficiary women $\left(\chi^{2}\right.$ $=0.362, \mathrm{df}=1,0.10>\mathrm{p}>0.05)$. This implies that enhanced livelihood assets are independent of educational level. The very low levels of education among the sheabutter processors probably caused the 
non-significant differences among the women in terms of enhanced livelihood assets.

Sai (1994) reported that education has been identified as one of the major components of empowerment and that education increases women's self-esteem and sense of control over personal destiny.

\section{Period of Membership in Groups and Enhanced Livelihood Assets}

The distribution of CLIP Project beneficiary women by period of membership in groups and enhanced livelihood assets is presented in Table 9. All the 54 beneficiary women, who have been members of their groups for less than four years, satisfied thirteen or more of the sixteen conditions for enhanced livelihood assets. The chi-square test results indicated that at 5\% confidence level, there was a significant difference between beneficiary women whose livelihood assets are enhanced and those whose livelihood assets are not enhanced with respect to the period of membership in groups $\left(\chi^{2}=4.260, \mathrm{df}=1,{ }^{* *} \mathrm{p}<0.05\right)$. The implication is that enhanced livelihood assets are influenced by period of membership in groups. It is possible that women who have been in the groups for a longer period of time would have probably received more training on sheabutter processing than those who have been in the groups for a relatively shorter period of time. The more training one receives, the more will be the possibility of enhanced livelihood assets.

\section{Discussion}

Livelihood assets are the basic livelihood building blocks. Booth et al. (1998) has reported that people's ability to escape from poverty is critically dependent on their access to livelihood assets. The livelihood framework identifies five core asset categories or types of capital upon which livelihoods are built. These include human, social, natural, physical and financial capital.

Livelihood strategies is used to denote the range and combination of activities and choices that people make or undertake in order to achieve their livelihood goals (including productive activities, investment strategies, reproductive choices, etc.). Poor people usually pursue a diverse portfolio of activities, including on-farm activities, off-farm activities and migration, using their livelihood assets.

The improved social capital of majority of the beneficiary women might be due to the network and connectedness as well as the relationship of trust that had been built among members of the groups. Sharing of ideas among group members regarding loan management and processing good quality butter might have improved marketing of the sheabutter leading to improved livelihoods. Sheabutter processing women who are in groups produced more and highly qualitative sheabutter than their counterparts who process the butter on individual basis. This is because members in these groups assist one another in processing quality butter and in good time. The co-operation and trust developed between the Community Life Improvement Program (CLIP) as an institution and members of the groups might have also contributed immensely in reducing the transaction cost of sheabutter micro-business of the beneficiary women, resulting in improved social capital. This finding is in consonance with the observation made by DFID (1999), who reported that social capital is developed through networks and connectedness, membership of more formalized groups, relationship of trust, reciprocity and exchange that facilitates cooperation, reduce transaction cost and may provide the basis for informal safety nets among the poor.

The study revealed that majority of the beneficiary sheabuter processing women had their human capital enhanced. It is possible that the skills development training that was organized for the rural women on methods and techniques of sheanut gathering, sheabutter processing, sheabutter storage and marketing might have equipped these rural women with local ecological knowledge and informal education to function effectively as micro-entrepreneurs and to improve upon their livelihood strategies. The quality sheabutter processed by the beneficiary women groups as compared with that of the non-beneficiary individual sheabutter processors was probably as a result of the training received from the CLIP Project. Ellis (2000) made similar observation and reported that human capital represents the skills, knowledge, formal and informal education, local ecological knowledge, ability to labour and good health that together enable people to pursue different livelihood strategies and achieve their livelihood objectives.

According to (DFID, 1999), financial capital refers to the financial resources that people use to achieve their livelihood objectives. It includes credit, savings and remittances. The provision of these financial resources helps to develop the financial capital of people. The CLIP Project provided the women microentrepreneurs with credit facility, adequate skill development training and portable water to help facilitate and improve their micro-businesses for improved livelihoods. The improved financial capital of the sheabutter micro-processors might probably be due to the financial and social intermediation services rendered by the CLIP Project.

The study established that sheabutter microprocessors kept the sheanut plantations clean of weeds and bush fires. Additionally, pruning of shea trees was periodically carried to enhance growth and production of shea trees. These agronomic practices observed by the sheanut processors might have resulted in increased 
yield of the sheanut crop. The fact that the shea plantations were kept clean of weeds and over-grown branches meant that incidence of occurrence of poisonous reptiles such as snakes and scorpions in the shea plantations would have reduced, thus health conditions of women groups would have improved, leading to uninterrupted sheanut gathering and sheabutter processing. The wood obtained from shea trees as a result of the pruning served as source of energy for the women to process the sheabutter and this might have reduced sheabutter production cost. The skills of pruning and the resources required to do pruning were all obtained from the CLIP Project. The information and knowledge obtained by the rural women to enable them maintain the shea plantation and acquire energy for sheabutter processing might have improved their physical/natural capital. This finding is in line with the observation made by DFID (1999) who reported that affordable transport, secure shelter and building, adequate water supply and sanitation, clean affordable energy and access to information are necessary for sustainable development of physical capital. DFID (1999) also reported that there is a wide variation in the resources that make up natural capital, from intangible public goods such as the atmosphere and biodiversity to divisible assets used directly for production (trees, land, e.t.c).

The study revealed that the CLIP Project has improved upon the livelihood strategies of the microentrepreneurs. The livelihood assets of the sheabutter processing women had therefore been enhanced through the development of the social, human, financial, physical and natural capital. This confirmed the observation made by Booth et al. (1998) that people's ability to escape from poverty is critically dependent on their access to livelihood assets and that people's livelihood assets are developed if their access to the social, human, financial, physical and natural capital is improved.

\section{Conclusion and Recommendation}

The study revealed that majority of the beneficiary women had their livelihood assets totally enhanced, whilst the livelihood assets of majority of the nonbeneficiary women were not enhanced. The study established that enhanced livelihood assets of CLIP Project beneficiary women were not dependent on educational level of project beneficiaries.

Enhanced livelihood assets of CLIP Project beneficiary women were completely dependent on period of membership of beneficiaries in groups.

It is therefore recommended that:

- $\quad$ The CLIP Project should extend its services to cover many more non-beneficiary sheabutter processors in the target communities
- The Project should expand its micro-credit and social intermediation services

- The Project should intensive its monitoring to attain the goals for which the micro-credits were given

\section{Acknowledgement}

We do acknowledge the logistical support of the Community Life Improvement Program (CLIP). We also acknowledge the critical comments and scientific inputs made by all researchers of the Department of Agricultural Extension, University of Ghana, Legon.

\section{Authors' Contributions}

This work was carried out in collaboration between all authors. Author AB designed the study, wrote the protocol and supervised the work. Authors AB and PBA carried out all laboratories work and performed the statistical analysis. Author SCA managed the analyses of the study. Author AB wrote the first draft of the manuscript. Author PBA managed the literature searches and edited the manuscript. All authors read and approved the final manuscript.

\section{Competing Interests}

Authors have declared that no competing interests exist.

\section{References}

Afrane, S., 2000. Impact assessment of microfinance interventions in Ghana and South Africa: A synthesis of major impacts and lessons. J. Microfinance, 4: 38-58.

Atengdem, P.B., 1997. Effectiveness and relevance of farmer's training: Lessons from Northern Ghana. PhD Thesis, AERDD, University of Reading.

Bell, J., 1993. Doing Your Research Project: A Guide for First-time Researchers in Education and Social Science, 1st Edn., Open University Press, UK., ISBN-10: 0335190944, pp: 176.

Booth, D., J. Holland, J. Hentschel, P. Lanjouw and A. Herbert, 1998. Participation and combined methods in African poverty assessment: renewing the agenda. Social Development Division, African Division, DFID, London.

Caldas, M., R.T. Walker, S. Perz, E. Arima and S. Aldrich et al., 2007. Theorizing land cover and land use change: The peasant economy of Amazonian deforestation. Annals Assoc. Am. Geographers, 97: 86-110. DOI: $10.1111 /$ j.1467-8306.2007.00525.x

DFID, 1999. Sustainable livelihood guidance sheet: Section 2. Department for International Development, London. 
Ellis, F., 2000. Rural Livelihoods and Diversity in Developing Countries. 1st Edn., Oxford University Press, Oxford, ISBN-10: 0198296967, pp: 273.

NCWD, 1997. Annual reports. National Commission for Women and Development, Accra, Ghana.

PHC, 2010. The 2010 Population and Housing Census (PHC) reports: Analysis of district data and implications for planning. Published by the Ghana Statistical Service, Accra, Ghana.
Sai, T.F., 1994. Adam and Eve and the Serpent. The 1994 Aggrey-Fraser-Guggisberg Memorial Lectures, Accra. The Ghana University Press. 